lore, the siting of shrines, and the overwhelming importance of St. George's day in the popular festal calendar. An inquiry on somewhat similar lines by Mr. Stuart Piggott traces Hercules, "the simple goodhearted strong man", back to Akkad, c. 2550 B.c., and in post-classical Europe down to Harlequin, a polished and sophisticated version of the god of the underworld. The discerning will note that Antiquity shows no falling off in demonstrating practically that solid learning need not be dull.

\section{Protecting Marine Cables}

ONE of the most prolific sources of damage to ocean cables is the heavy drags, called otterboards, which are attached to the nets of steam trawlers and dragged along the ocean bottom. In the Nickel Bulletin of September, it is estimated that the damage caused to cables by the steel runners of otterboards averages about $£ 100,000$ a year. To get rid of this source of loss, the Western Union Telegraph Co. has, for some time, been experimenting with a submarine plough which will automatically make a furrow in the bottom of the ocean, feed the cable into it and cover it up. The cable will then be buried at a depth sufficient to ensure that the otterboards cannot come into contact with it. Encouraging results have been obtained from experiments made so far, but many difficulties have had to be faced. A new series of experiments has now been started off the Irish coast. The plough is towed by the cable-ship Lord Kelvin. In handling the equipment a very flexible towing line had to be provided able to withstand a load of 29 tons. 'The ordinary equipment necessitates that the line must be neither too light nor too rigid. It must be capable of being paid out gradually from the ship while ploughing under full load. After careful investigation and a series of tests it was found that 'di-lok', a special chain made of $3 \frac{1}{2}$ per cent nickel-steel, was quite suitable. In order to get continuously smooth operation a very minute tolerance on the size and shape of each individual link was imposed. The requirements were about five times as severe as those imposed by the U.S. Navy in their specifications. There are eleven Western Union trans-Atlantic cables and eight of these pass through fishing areas off the Irish coast where most of the ploughing work will be carried out.

\section{Carnegie Institution of Washington}

A VALUABLE addition to the administration build. ing of the Carmegie Institution of Washington has for some time been under construction and will probably be completed in time for the usual Institution lectures in late October or early November. The new structure has been designed primarily to facilitate develop. ment of the public relations programme of the Institution by improving conditions for handling its publications, and for more direct contacts with the public through lectures, conferences and exhibitions. The principal room in the addition is an auditorium, designed to seat about five hundred, which, under the name of Elihu Root Hall, is being dedicated to the memory of Mr. Root. Up to the present time the facilities for lecture programmes have been limited to a room seating comfortably about half that number, and it has been necessary in most cases to limit invitations to those who have something more than a general interest in the subjects presented. With the accommodation now in prepara. tion it will be possible to include a larger invitation list with freedom to invite men of science and laymen representing all fields of interest. Committee and conference rooms have been designed for the special purpose of arranging for discussions with a limited group of special students of subjects under consideration, and thus promote inquiries and research into the particular field of natural knowledge in which they are engaged.

THE exhibitions of the Institution held in recent years at the time of the annual meeting have served an important purpose in bringing together representatives of all the departments and in presentation of some of the most important results of their researches. These contacts have had much value in development of co-operative relations between research groups of the Institution. The exhibitions have also served an important purpose in that they make possible the contact of the Trustees at the time of the annual meeting with all of the departments, especially through giving opportunity to see results of some of the most interesting investigations. In past years, the annual exhibition has been possible only by use of the regular offices of administration, to the exclusion of much of the ordinary business at the time of the annual meeting. The new building will include rooms which are much more commodious and better organized for exhibition purposes than those thus far available, and use of these quarters will permit the regular business of the administrative offices to be carried on during the period of the annual meeting. The new exhibition rooms will also permit certain exhibits at the administration headquarters to be retained throughout the year if this seems desirable.

\section{The Institution of Professional Civil Servants}

THE nineteenth annual report, for 1937 , of the Council of the Institution of Professional Civil Servants refers to the spectacular increase in membership from 9,076 in 1935 to 13,896 at the end of 1937. Activities of the Institution during the year were directed largely to obtaining improvements in the salary scales of its members. Despite the multiplicity of grades and salaries, considerable success has been achieved both by negotiation and by arbitration. The common scale possessed by certain architectural surveying and civil engineering grades in the Civil Service enabled the Institution to secure improved salary scales by central discussion, and acceptance of the Institution's proposals for the simplification of grades and salaries of the professional, scientific and technical classes in the Civil Service which were submitted to the Tomlin Commission would greatly reduce the task of negotiation and lighten the work of the departmental establishment officers. The Institution has also participated in the work of the National Whitley Council, and the report includes a full account of 